\title{
Evolving Host Socio-Demographical Determinants Towards Himalayan Handicraft Industry
}

\author{
Suman Sharma, Central University of Himachal Pradesh, India* \\ Satyajit Sinha, Central University of Himachal Pradesh, India \\ (iD https://orcid.org/0000-0002-1482-2385 \\ Debasis Sahoo, Central University of Himachal Pradesh, India
}

\begin{abstract}
Himachal Pradesh is widely known for its beauty, culture, and heritage. The handicrafts of this region maintain cultural integrity among themselves and show it to the rest of the world. This paper aims to investigate the dynamics of socio-demographic variables based on community-based host motivators (CBHM) involved in handicraft tourism in Himachal Pradesh. To conduct this study, a field survey of 277 members of the host community was piloted from December (2020) to January (2021) using a structured questionnaire. Four factors of motivation at the community level were derived: tourism, government efforts, advertising and social indicators, and employment indicators. The results highlighted the relationship between government efforts and all CBHMs; qualifications strongly influenced tourism, government efforts, and advertising factors while government initiatives have greatly contributed to the empowerment of women. In contrast, the nuclear family has more decision-making power than the joint family with regard to CBHMs.
\end{abstract}

\section{KEYWORDS}

Community-Based Tourism, Exploratory Factor Analysis, Handicraft Tourism, Himalayan Region, Host Community Motivators, Kruskal Wallis Test, Socio-Demographical Determinants

\section{INTRODUCTION}

In today's fast growing economy, tourism is one of the key drivers. India is among the popular tourist destinations in Asia. Indian tourism has stimulated dying interest and activity in several areas of the virtual and performing arts and crafts and has provided markets for goods that could never be supported by local demand; this is especially true for handicrafts (Joshi \& Dhar, 2020). Handicrafts are unique handcrafted items made using simple tools with a decorative character that play a vital role in representing the culture and traditions of a region, as in the case of Himachal Pradesh. Himachal Pradesh is widely known for its hand-woven weaving and handicrafts, ranging from Chamba Rumal, miniature paintings of Kangra, Metal works, Himachali Topi, Kulu shawls and many others (Chawla, 2020). There is evidence that these products have a deep ancient history (Aryan \& Gupta, 1993). The raw materials used in these products are unique in nature and are only found locally (HPTDC, 
2021). The craft symbolizes its associated heritage, cultural traditions, craftsmanship and aesthetic creativity (Dasgupta \& Chandra, 2016).

\subsection{Handicraft and Tourism}

Handicraft tourism can support the environment and local economy in a balanced way (Mustafa, 2011) (Oyekunle, 2018). Government policies, support, assistance and training do affect the smooth running of handicraft production (Toops, 1993). Handicraft tourism of Himachal Pradesh (H.P) has huge potential for growth in both local and national economy (Joshi \& Dhar, 2020). These includes contributions to gross domestic product, foreign exchange earnings, job creation through handicrafts and contributes to overall social development (Naidu et al., 2016; Purnomo, 2021). According to a report by IMARC (2020) group, the global value of handicrafts sector in 2020 was 718 billion US dollars, and is expected to grow by $10 \%$ during 2021-2026. The group is continuously monitoring the uncertainties and indirect influences of COVID-19 on various end-use industries, such as the tourism industry. As of 2020 tourism sector contributed 7.2 percent of the state (H.P) gross domestic product (GDP) (IBEF, 2020) and already generated 4.2 million jobs directly or indirectly (NCAER, 2020). The Infrastructure Development Investment Program for Tourism Financing Facility proposed to develop and improve basic urban infrastructure and services in in H.P state, and side by side H.P tourism proposed establishment of centre for traditional arts and crafts in Badangran, Manali, to ensure the promotion of the traditional handloom and handicraft practices in this way, so that it is beneficial to the local communities and portrays Himachal's vibrant culture from a wider perspective (Chawla, 2020). The policy of the state and the centre aimed at improving the skills of artisans brings related benefits. Of the 12 Himalayan states of India; Himachal Pradesh attracts a huge number of tourists every year. At the end of the trip, these tourists buy handicrafts as souvenirs or for permanent use. These products have also been featured on many marketplaces, retail outlets and trade fares (Nayak \& Bhalla, 2016). In 1974 Himachal Pradesh State Handicrafts \& Handlooms Corporation Limited (HPSH\&HCL) was established with the sole purpose of helping and advancing the interests of the state's marginalized weavers and artisans. The corporation was intrusted with the responsibility of training, providing raw materials, reviving languished crafts, giving design inputs and facilitating marketing connectivity through the network of emporiums located within and outside the states (HPSH\&HCL, 2010).

Figure 1. Handicraft of Himachal Pradesh
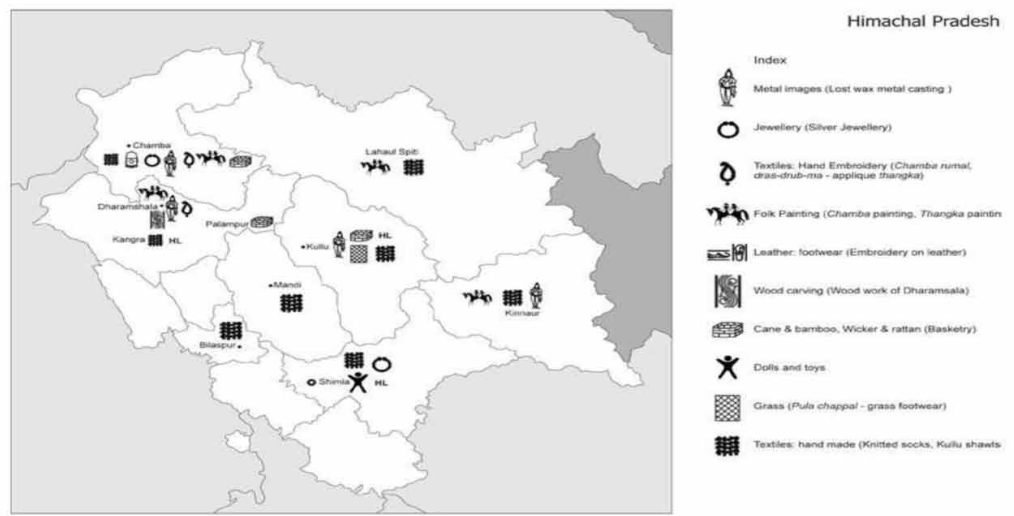

Source: Craft council of India 
Even after lot of promotion, these products face a sharp drop in demand due to fierce competition from industrial manufactured goods (Oyekunle, 2018), or artisans receive very low business profits to depend entirely on the craft business for survival (Ghouse, 2012). Majority of the handicraft production units located in small villages are on a small scale, where awareness of government initiatives is an issue (Ibrahim, 2010). Scholars argue that the right synchronization of consumer taste, budget, and craft production leads to the success of a handmade product (Ghouse, 2012). Local handicrafts are a sensual, complex culture that combines social traditions, creative and artistic aspects. Applying consumer behaviour skills will significantly increase the demand in the artisanal tourism industry and tend to increase the income and dependence of skilled craftsmen (Dasgupta \& Chandra, 2016).

However, so far, the majority of the existing literature on handicraft tourism has focused on tourists handicraft buying motives (Altintzoglou et al., 2016; Chan et al., 2021; Dasgupta \& Chandra, 2016; Militz et al., 2021; Nayak \& Bhalla, 2016) or handicraft innovativeness and its market reach (Ferreira et al., 2019; Ghouse, 2012; Joshi \& Dhar, 2020; Naidu et al., 2016; Oyekunle, 2018; Teo et al., 2020; Toops, 1993). We found a gap in the research on the factors that motivate(s) host community stakeholders to be in the handicraft industry. Thus, the main purposes of this study were to investigate the relationship between host socio-demographic indicators and the factors that are driving the host communities' motivation(s) to be in the Himachali handicraft business sustainably in long run.

This article focuses on the Himalayan state of H.P for two reasons. First, there have been limited studies on handicrafts in the Himalayan region as compared to other regions around the world. This is a pioneering study that examines the handicraft stakeholders' motivation in the region. Secondly, handicraft industry in H.P reaches to grass root level. Therefore, it is needed to conduct a study that will bring in notice the evident factors effecting the performance of handicraft industry and standard of living of grass root level stakeholders'. The majority of the individuals involved in handicraft industry of H.P are locals; hence, it is decisive to conduct a study that will benefit individuals from low income strata.

\section{LITERATURE REVIEW}

\subsection{Influence of Tourism on Handicraft Stakeholders}

As the tourism industry has emerged as a leader in providing employment opportunities worldwide and helps in increasing country's revenue through multiple sectors, which also include handicrafts offerings to tourists (Binns \& Nel, 2002). The increasing contribution of handicrafts to the economy of any country has been seen in contributing to their economies from last few decades but the question regarding to what extent the sales of these handicrafts supports the livelihoods of local people. The profit earned by local people from the sale of these local handicrafts is just sufficient to meet the cost of their livelihoods. It has been realized from various studies which were done previously that this segment has immense potential and can further help in strengthening local people and communities all together resulting in sustainable tourism development.

Brunt \& Courtney, (1999) has examined craftsmen perception of the sociocultural and socio demographic impact of tourism on handicraft industry. It identified three main refrains tourist and host cultural interaction, socio- cultural influence of tourism on the host community. The authors conclude that tourism has altered the life of the craftsmen's community. The study describes both positive and negative attitude apparently having little relation to the type of respondents towards host community upliftment through handicraft tourism. Moreover, Mbaiwa, (2004) discusses the concept of sustainable rural livelihoods and income diversification to assess the role that basket making as a cultural tourism activity can play in improving rural livelihoods in the Okavango Delta, Botswana. Using both primary and secondary data sources, the article points out that shocks and natural causes such as drought, disease and changing flood levels in the Okavango River, particularly the drying of the Thaoge (one of the distributaries of the Okavango), have contributed to a decline in livestock and crop yields and increased poverty levels in the region. Therefore, alternative livelihood options that can diversify rural 
incomes from agricultural production need to be identified. This paper argues that basket making has the potential to diversify rural incomes and improve livelihoods in the Okavango. Baskets are a cultural tourism product that can contribute to income earnings and employment opportunities for rural residents in the Okavango. These resources are at present overharvested and are threatened with depletion. The author identified the need to promote the empowerment of basket weavers particularly in entrepreneurship and managerial skills in the tourism business, attract young and educated people and promote the preservation of traditional basket making skills, which are important in the development of cultural tourism. Handicrafts form an integral part of tourist experience and represent tradition of indigenous population. Local communities get directly benefited by handicraft tourism as provider of income and job opportunity (Mustafa, 2011). Handicraft represents the 'indegeneity' related to nature or tradition. Handicraft tourism gives a representation to locals and makes it important marker of identity for indigenous and non-indigenous actors (Keskitalo et al., 2021).

In another attempt Teo et al., (2020) conducted their study aiming to examine the external environment that influence the handicraft industry, analyze the challenges faced by the industry and also made recommendations for future research into the handicraft design. To examine the external environment, the researchers employed the PEST analysis method which evaluates the political, economic, social and technological environment in which industry operates. The Findings reported that government supports handicraft industry in terms of capital and financial assistance, providing incentives to producers as well as foreign investors, establishing training centres etc. as the industry aids in creating job opportunities, reducing unemployment and poverty for people residing at rural areas of Vietnam city. The study also figure out the challenges faced by the industry by adopting Michel Porter's Five Forces framework which includes rivalry among competitors, threat of new entrants, bargaining power of suppliers, bargaining power of customers and threat of substitution. The research findings reflect that due to homogeneity of products, low production cost and capital requirement, the industry is facing threats from competitors, new entrants, suppliers and buyers for which excellent skills are required to meet the situation. The authors also assess the competitiveness of Vietnam handicraft industry by using VRIO framework in which four types of resources were examined namely raw material, brand name, expertise and design of the handicraft industry, and resulted that these resources are in parity competitive advantages in terms of valuation, rarity and imitation . To achieve this, authors recommended that the handicraft industry should focus on product and design differentiation and innovation so as to expand the handicraft industry to the large and global market.

\subsection{Tourist Buying Behaviour}

Littrell et al., (1993) carried out a study to broaden understanding of souvenir consumption through empirical examination of the concept of authenticity in craft souvenirs. Descriptions of craft authenticity from 385 Midwestern US tourists were content analyzed for prominent themes. Criteria used by tourists to define authenticity included a craft's uniqueness, workmanship, aesthetics and use, cultural and historical integrity, and genuineness. Characteristics of the craftsperson and the shopping experience also contributed to authenticity. Definitions of authenticity varied with tourists' ages, stage of travel careers, and tourism styles, but not with tourists' gender. Elaboration and refinement of the definition of souvenir authenticity is recommended with non-hand-produced souvenirs and with tourists in other regions of the U.S.

Furthermore, Dash, (2010) elaborated that craftsmanship of the arts and crafts embodies a tradition, which lives in the creative imagination of the artists of Orissa. The beauty and charm of its crafts has always been a source of attraction to many Indian and foreign tourists. Today Orissa handicrafts are thus reaching all corners of the world. A clear understanding of consumer behaviour can give marketers a better idea of how marketing works, enabling them to devise more potent marketing strategies. Usually out-dated designs do not attract buyers. In keeping with the changes in consumer tastes and preferences, artisans have to change their crafts. With change in the outlook of the present customers, artists have to work accordingly, which can fulfil the requirements of the 
customers. So artists, in order to satisfy and promote this business, should know the art of modern making and work according to the taste of the customers.

Henceforth, Nayak \& Bhalla, (2016) explored factors motivating visitors for attending handicraft exhibitions special focus on the Himalayan state of Uttarakhand with descriptive statistics and exploratory factor analysis. Place of exhibition and promotion campaign mostly attracted buyers. The researcher argued attractive travel destination, and attraction due to media or advertisement through social media or television appeared to be major motivators for attracting more tourists cum buyers. The demographic profiling of the research show case that majority of the buyers is from the younger generation. Visitors do have high handicraft purchase participation rate if they are pitched by the accompanying guide or the travel companies. Discounts, offers, meeting artisans or onsite manufacturing do boost sale of the handicrafts. But end of the day customers needed to be dealt with patience as one customer may influence another. Tourists in higher income bracket have high chances of purchasing handicrafts. Setiyati \& Indrayanto, (2011) established that the existence of overseas-made souvenirs is of great concern recently following the global pattern of "outsourcing" production. Often negative discussion appears to be the result of the growing number of souvenirs that are being produced overseas, which then to be sold at relatively lower prices compared with locally-manufactured souvenirs. The aforementioned condition is a problematic area because it may cause authenticity anxiety for tourists, reduce the income of local craftsmen and manufacturers, as well as pose a threat to the future of the local tourism industry. The research elaborated how outsourced (overseas-made) souvenirs are perceived by tourists in comparison to those that are locally-made in the host country. A case study of Australian souvenirs industry is provided in order to gain a valuable insight of this issue. Some behavioural issues with regard to the purchase of authentic souvenirs are also discussed to gain a better understanding of the market demand.

\section{OBJECTIVES}

The objective of this study is to investigate the quantitative relationship between host sociodemographic indicators (i.e. gender, age, qualifications, family type and occupation) and community based host motivating (CBHM) factors towards continuation of handicraft business in H.P.

\section{METHODOLOGY}

Given the fundamental exploratory nature of the study, it used a survey that contained quantitative items constructed on the suggestion of the experts (Ashton \& Goldberg, 1973; Hogan \& Murphy, 2007; Ormshaw et al., 2016) consisting of handicraft manufacturers, government emporium managers, academicians from National Institute of Fashion Technology (NIFT-Kangra, H.P), handicraft selling intermediaries and H.P tourism officials. Due to the limited availability of valid scales focused on community based host motivation for handicraft business in the literature this exploratory study was carried out (Deale \& Lee, 2021; Fadda, 2020) to examine a gap that has not been addressed very specifically and is intended to gather preliminary information that may help for more focused investigation in the future (Kotler \& Hall, 2004).

An initial pool of 42 items was generated based on the review and analysis by the panel of experts to access the appropriateness and generality of the items. A pilot study was conducted with a group of 47 stakeholders in Manali, H.P to assess the format and clarity of the items. Based on the panel recommendation and pilot study, 31 items were retained. Reliability analysis of 31-item scale was piloted, 5 items were discarded as they had a low $(<0.40)$ factor loading (Hinkin, 1995).

Finally, requisite data was collected in three phases in the month of December (2020) and January (2021) by administering questionnaire directly to the host community members involved directly or indirectly in the handicraft trade of Himachal Pradesh with the help of a field investigator. Out of 
total 348 administered questionnaires only 277 was returned usable. It took about 25 minutes to fill up each questionnaire.

\section{Table 1. Findings of factor analysis}

\begin{tabular}{|c|c|c|c|c|}
\hline Factors (Cronbach's Alpha) & Eigenvalue & $\begin{array}{l}\text { Percent of } \\
\text { Variance }\end{array}$ & $\begin{array}{l}\text { Grand } \\
\text { Mean* }\end{array}$ & Sig \\
\hline Factor 1 (0.938):Tourism & 12.22 & 39.44 & 5.37 & 0.0000 \\
\hline \multicolumn{5}{|l|}{ My handicraft products are been sold as souvenir } \\
\hline \multicolumn{5}{|c|}{ Tourism industry is the major contributor for my product sale } \\
\hline \multicolumn{5}{|l|}{ I feel Handicraft products attracts tourists } \\
\hline \multicolumn{5}{|l|}{ I am benefited by tourism industry } \\
\hline \multicolumn{5}{|l|}{ Better logistics supply and market connectivity } \\
\hline \multicolumn{5}{|c|}{ Tourism seasonality affects sales/ purchase of the handicraft products } \\
\hline \multicolumn{5}{|c|}{ Importance of local cultural functions and festivals has increased } \\
\hline \multicolumn{5}{|l|}{ Opportunity to meet new customers } \\
\hline \multicolumn{5}{|c|}{ Handicraft provides a broader market for destination promotion } \\
\hline Factor 2 (0.927): Government Efforts & 5.22 & 16.82 & 5.22 & 0.0000 \\
\hline \multicolumn{5}{|c|}{$\begin{array}{l}\text { Government provides initiatives, aids or subsidies in handicraft } \\
\text { manufacturing }\end{array}$} \\
\hline \multicolumn{5}{|l|}{ Easy procurement of tools equipment and machinery } \\
\hline \multicolumn{5}{|c|}{ Assistance in Technology Support by any Govt. or non Govt. agencies } \\
\hline \multicolumn{5}{|c|}{ Self-help groups are providing training and skill development programmes } \\
\hline \multicolumn{5}{|c|}{ Government helps in creating new markets for Himachal handicrafts } \\
\hline \multicolumn{5}{|c|}{ Easy availability of raw material } \\
\hline \multicolumn{5}{|l|}{ Increased in cheating and fraud } \\
\hline Factor 3 (.901): Promotional-Socio indicators & 3.09 & 9.98 & 4.35 & 0.0000 \\
\hline \multicolumn{5}{|c|}{$\begin{array}{l}\text { Time, effort and money is required in promotion activities of the } \\
\text { handicrafts }\end{array}$} \\
\hline \multicolumn{5}{|c|}{ Promotion of local handicraft by Exhibition and handicraft trade fairs } \\
\hline \multicolumn{5}{|c|}{$\begin{array}{l}\text { Participation by local community in trade fair and exhibition helps in } \\
\text { increase sales volume }\end{array}$} \\
\hline \multicolumn{5}{|l|}{ Living Standard has increased } \\
\hline \multicolumn{5}{|l|}{ Helped in removing Social Barrier } \\
\hline \multicolumn{5}{|l|}{ Local economy boosted by handicraft business } \\
\hline Factor 4 (.919): Employment Indicators & 1.74 & 5.63 & 4.7 & 0.0000 \\
\hline \multicolumn{5}{|l|}{ Increased value of services } \\
\hline \multicolumn{5}{|l|}{ Tourism has commercialized local handicraft } \\
\hline \multicolumn{5}{|l|}{ Enhanced your language skills } \\
\hline Hike in demand for traditional art and craft & & & & \\
\hline
\end{tabular}


The questionnaire consisted of three main sections: questions to construct host member's profile; handicraft related information; and rating scales with each item was situated in seven pointer Likert scale format (Jaeschke et al., 1990) with 1 as 'Strongly Disagree' and 7 as 'Strongly Agree' for a list of 26 community based host motivators (CBHMs) (see Table 1) to understand community development by handicraft tourism (Balakrishnan Nair \& Sinha, 2020; Altintzoglou et al., 2016; Kaplanidou \& Vogt, 2007). Our analysis was directed to calculate the variations in respondents with respect to CBHMs.

The recorded data was analysed using SPSS version 26 by applying two types of tests. Firstly an exploratory factor analysis (Kuo et al., 2008; Balakrishnan Nair \& Sinha, 2020) was carried out to reduce selected 26 CBHM items into four orthogonal factors (see Table 1) both to just reveal hidden factors (Kozak, 2002). Secondly, to examine statistical variance $(\mathrm{p}<0.05)$ between the factor sets across different socio-demographical variables, a set of two inferential non parametric test was deployed (see Table 2), which includes the Mann-Whitney U test (Contreras-Joya et al., 2015) on Gender and Family type and Kruskal-Wallis test on other categorical variables. Non parametric test was applied on the data set as data violated assumptions of normality (Batra, 2009).

\section{DATA ANALYSIS AND RESULTS}

Factor loading items (9) related to host motivators associated with tourism contribution, tourism involvement and other tourism related indicating factor No .1 (see Table 1). Motivators (7) related to government efforts to uplift community through handicraft tourism by various skill enhancement training programmes, advance technology and other related efforts like availing raw materials, essential tools for manufacturing handicrafts and giving aids, subsidies to support the loss-profit gap. In contrast, the third factor (6) may be construed as community based host motivators based on promotional - socio indicators whereas the forth factor (4) comprised of items related to employment indicators. The mean ranks of independent groups of variables were compared for each of the CBHM sets. The comparison explained the difference of relation between each Sociodemographic variables with respect to the CBHMs (Sinha \& Nair, 2020).

\subsection{Gender}

Out of the four CBHMs two were significantly influenced by gender namely government efforts and promotional- socio indicators. For CBHM 2 females had the highest mean rank (see Table 2) compared to their male counterpart indicating government efforts has more motivated females compared to males however promotional - socio indicating factors (CBHM 3) have motivated male host community members more than females members.

\subsection{Age}

The age variable is categorised into four groups where there were no respondents from under 20 years category (see Table 2). Respondents' age group had a significant effect on the 'tourism' and 'government effort' motivators but did not significantly influenced rest of the two motivators' i.e CBHM 3 and CBHM 4. Participants between the age group 20-40 and 40-60 had highest mean rank for CBHM 1 and CBHM 2 respectively, which represent the level of influencing by different category of age groups.

\subsection{Qualification}

Findings (see Table 2) in the current category unveils that qualification had a significant effect on all four sets of CBHMs. Host respondents affianced to handicraft business with highest education of graduation higher significant level in all four CBHM sets compared to their other counter parts. Thus, middle order education catalytically effect community based host motivators in handicraft business (Kim et al., 2018). 
Table 2. Socio-demographic variable analysis result-Mann Whitney u test and Kruskal Wallis test

\begin{tabular}{|c|c|c|c|c|c|c|c|c|c|c|}
\hline \multirow{2}{*}{\multicolumn{3}{|c|}{ Socio-Demographic variables }} & \multicolumn{8}{|c|}{ Community based host motivation factors } \\
\hline & & & \multicolumn{2}{|c|}{ СВНM 1} & \multicolumn{2}{|c|}{ СВНМ 2} & \multicolumn{2}{|c|}{ СВНМ 3} & \multicolumn{2}{|c|}{ CВHМ4 } \\
\hline Variables & Description & $(\mathrm{N}=277)$ & $\begin{array}{l}\text { Mean } \\
\text { Rank }\end{array}$ & $\mathrm{Z} / \chi^{2}$ & $\begin{array}{l}\text { Mean } \\
\text { Rank }\end{array}$ & $\mathrm{Z} / \chi^{2}$ & $\begin{array}{l}\text { Mean } \\
\text { Rank }\end{array}$ & $\mathrm{Z} / \chi^{2}$ & $\begin{array}{l}\text { Mean } \\
\text { Rank }\end{array}$ & $\mathrm{Z} / \chi^{2}$ \\
\hline \multirow{2}{*}{ Gender } & Male & 178 & 144.8 & \multirow{2}{*}{-1.619} & 121.24 & \multirow{2}{*}{$-4.955 * * *$} & 150.17 & \multirow{2}{*}{$-3.125 * *$} & 144.1 & \multirow{2}{*}{-1.424} \\
\hline & Female & 99 & 128.57 & & 170.93 & & 118.91 & & 129.84 & \\
\hline \multirow{4}{*}{$\begin{array}{l}\text { Age } \\
\text { (years) }\end{array}$} & Under 20 & 0 & $\mathrm{n} / \mathrm{a}$ & \multirow{4}{*}{$9.287 *$} & $\mathrm{n} / \mathrm{a}$ & \multirow{4}{*}{$13.942 * *$} & $\mathrm{n} / \mathrm{a}$ & \multirow{4}{*}{1.226} & $\mathrm{n} / \mathrm{a}$ & \multirow{4}{*}{1.726} \\
\hline & $20-40$ & 122 & 154.45 & & 133.80 & & 136.18 & & 144.93 & \\
\hline & $40-60$ & 148 & 128.35 & & 148.13 & & 139.85 & & 135.34 & \\
\hline & Above 60 & 7 & 95.00 & & 36.50 & & 170.00 & & 113.00 & \\
\hline \multirow{4}{*}{ Qualification } & Under 10th & 164 & 128.81 & \multirow{4}{*}{$28.919^{* * * *}$} & 134.63 & \multirow{4}{*}{$9.477^{*}$} & 140.16 & \multirow{4}{*}{$36.914 * * * *$} & 125.82 & \multirow{4}{*}{$38.595^{* * * *}$} \\
\hline & $\begin{array}{l}\text { Higher } \\
\text { Secondary }\end{array}$ & 77 & 135.82 & & 136.27 & & 125.41 & & 139.95 & \\
\hline & Graduate & 29 & 213.16 & & 179.62 & & 199.40 & & 222.45 & \\
\hline & $\begin{array}{l}\text { Post } \\
\text { Graduate } \\
\text { and above }\end{array}$ & 7 & 105.50 & & 103.00 & & 11.00 & & 91.50 & \\
\hline \multirow{2}{*}{$\begin{array}{l}\text { Family } \\
\text { Type }\end{array}$} & Joint & 165 & 140.02 & \multirow{2}{*}{-0.257} & 120.50 & \multirow{2}{*}{$-4.672 * * *$} & 143.09 & \multirow{2}{*}{-1.037} & 130.24 & \multirow{2}{*}{$-2.215^{*}$} \\
\hline & Nuclear & 112 & 137.50 & & 166.25 & & 132.97 & & 151.91 & \\
\hline \multirow{9}{*}{ Occupation } & Artisans & 14 & 248.50 & \multirow{9}{*}{$196.365^{* * * *}$} & 270.50 & \multirow{9}{*}{$190.584 * * * *$} & 246.75 & \multirow{9}{*}{$156.614^{* * * *}$} & 248.50 & \multirow{9}{*}{$197.327^{* * * *}$} \\
\hline & $\begin{array}{l}\text { Bamboo } \\
\text { Craft }\end{array}$ & 49 & 44.00 & & 114.50 & & 145.29 & & 71.64 & \\
\hline & Ceramist & 36 & 251.33 & & 43.68 & & 237.33 & & 252.69 & \\
\hline & Farmer & 28 & 133.38 & & 84.63 & & 56.63 & & 110.00 & \\
\hline & $\begin{array}{l}\text { Handloom } \\
\text { Weaver }\end{array}$ & 80 & 112.08 & & 174.37 & & 104.77 & & 120.96 & \\
\hline & $\begin{array}{l}\text { House } \\
\text { Keeper }\end{array}$ & 21 & 115.17 & & 86.67 & & 56.50 & & 61.83 & \\
\hline & pine craft & 35 & 197.10 & & 234.90 & & 166.50 & & 208.60 & \\
\hline & Travel agent & 7 & 141.50 & & 117.00 & & 138.00 & & 60.00 & \\
\hline & Trekking & 7 & 116.00 & & 50.50 & & 205.50 & & 91.50 & \\
\hline
\end{tabular}

Note: (1.) CBHM1-CBHM4 refer CBHM1 (Tourism) CBHM2 (Government Effort) CBHM3 (Promotional - Socio indicators) CBHM4 (Employment Indicators) $(2 .)^{*} p<0.05,{ }^{* *} p<0.01,{ }^{* *} p<0.001$ (3.) Mann Whitney $U$ test was conducted for Gender and Family type.

\subsection{Family Type}

"Promotional - Socio indicators" and "Employment indicators" profoundly influenced by variable Family type (see Table2); Nuclear family has a significant strong effect over the above mentioned CBHMs compared to their counterpart Joint family host members. This indicates Nuclear family community members have more decision making power than joint family members in the lines of earlier research (Koenig Kellas \& Trees, 2006) to pursuit promotional-socio factors or employment factors related to handicraft business.

\subsection{Occupation}

Total nine subcategories of profession from different verticals of handicraft business participated in the data collection process (see Table 2). Occupation exhibited significant effects for all four community based 
host motivators. Artisans had highest mean rank throughout all the four CBHMs indicating they influence all the motivators' utmost followed by ceramist and pine craftsmen.

\section{DISCUSSIONS AND CONCLUSION}

This study focuses on the socio demographical dimension of handicraft tourism in the Himalayan state of Himachal Pradesh, which is often ignored. Handicraft preserves the decades or century old culture, craftsmanship, pre-industrial techniques, identity of the region and strengthens the identity and dignity of the people. Financial and environmental sustainability of host community involved in handicraft business depends on socio-environmental aspects, tourism demand, government and non-government organisational efforts and inclusive employment factors with collaboration from all key stakeholders (Nair, Bipithalal Balakrishnan; Dileep, 2020).

To establish a profitable handicraft business in a tourist destination pre requisite efforts are desirable on the grounds of socio-economic, cultural sustainability, promotional campaigns through multiple mediums and government motivation. At any cost local communities' quality of life cannot be compromised; Moreover, these stakeholders should be active in managing handicraft resources and jointly engaging in interactions with tourists.

This study observed that notable number of women participation in this sector and women empowerment aspect highly influenced government efforts in developing handicraft tourism in the region where as male community of the society engaged in promotional and social efforts. They have high contribution in upbringing the livelihood and removing the social barriers from the social structure of the society. The findings demonstrate that tourism motivators were highly influenced by age, qualification and occupation variables. One of the novel characteristics of this research project is to check the influencing variables on handicraft tourism; it indicates host community age, qualification with respect to their occupation significantly instigates handicraft tourism. Secondly, government efforts gets instigated by all the selected five socio-demographic variables initiatives like providing subsidies, giving training support, creating new market and to boost the morale of the stakeholders. Thirdly, qualification and occupation influenced promotional and socio factors indicating higher qualification will have an edge on extracting benefits from handicraft promotional activities and other social benefits. Lastly employment is impossible without required qualification, family support whereas level of skill will decide the type of occupation a stakeholder can engage with.

\subsection{Practical Implication}

This research adds evidences to the pool of Himalayan handicraft tourism by widening current practical understanding of the host community engagement in handicraft business and the factors supporting and influencing them. Successful application of sustainability in handicraft tourism may uplift the demand of the products and bring it at the edge in the product life cycle. The underlying rational of this research will be helpful for the managerial bodies engaged in tourism as well as handicraft business, particularly to improve the sustainability of the current situation of handicraft trade/ employing new initiatives concentrating on local communities' skill and trade aspect/ for handicraft tourism policy making by the policy makers to increase the volume of trade and tourist engagement.

\subsection{Limitations and Avenues for Future Study}

However, this study has few limitations. First, it considered host stakeholders from seven out of twelve districts of H.P due to time and fund constraints, the study may be conducted on a larger scale in the future. Secondly, while considering socio-demographic indicator, the income of the stakeholders is not taken into account, which can be considered in future studies. Finally due to covid-19 protocol the researcher was unable to collect qualitative data that could add more richness to the findings of this study. Therefore, a longitudinal qualitative study is recommended in future. 
International Journal of Asian Business and Information Management

Volume $12 \cdot$ Issue 3

\section{ACKNOWLEDGMENT}

The research was conducted with the support of Indian Council of Social Science Research (ICSSR), New Delhi academic research grant no. SoTTHM/1-13/CUHP/ICSSR-MRP/2019-20/484. 


\section{REFERENCES}

Altintzoglou, T., Heide, M., \& Borch, T. (2016). Food souvenirs: Buying behaviour of tourists in Norway. British Food Journal, 118(1), 119-131. doi:10.1108/BFJ-05-2015-0190

Aryan, S., \& Gupta, R. D. (1993). Crafts of Himachal Pradesh. Mapin Publishing Pvt Ltd.

Ashton, S. G., \& Goldberg, L. R. (1973). In response to Jackson's challenge: The comparative validity of personality scales constructed by the external (empirical) strategy and scales developed intuitively by experts, novices, and laymen. Journal of Research in Personality, 7(1), 1-20. doi:10.1016/0092-6566(73)90028-7

Batra, A. (2009). Senior Pleasure Tourists: Examination of Their Demography, Travel Experience, and Travel Behavior Upon Visiting the Bangkok Metropolis. International Journal of Hospitality \& Tourism Administration, 10(3), 197-212. doi:10.1080/15256480903088105

Binns, T., \& Nel, E. (2002). Tourism as a local development strategy in South Africa. The Geographical Journal, 168(3), 235-247. doi:10.1111/1475-4959.00051

Brunt, P., \& Courtney, P. (1999). Host perceptions of sociocultural impacts. Annals of Tourism Research, 26(3), 493-515. doi:10.1016/S0160-7383(99)00003-1

Chan, Y. S., Yee, W. L., \& Wan, L. L. (2021, March 16). Consumers' Buying Behaviour on Malaysian Traditional Handicrafts. Conference on Management, Business, Innovation, Education and Social Sciences. https://journal. uib.ac.id/index.php/combines/article/view/4411

Chawla, A. (2020). Centre for Traditional Art and Craft, Manali Himachal Pradesh. http://dspace.spab.ac.in:8080/ xmlui/handle/123456789/1400

Contreras-Joya, M., Jiménez-Martín, A., Santos-Yubero, F. J., Navarro-Martínez, S., Najarro-Cid, F. J., SánchezSotelo, J., \& Pérez-Hidalgo, S. (2015). Radial head arthroplasty, 11 years' experience: A series of 82 patients. Revista Española de Cirugía Ortopédica y Traumatología, 59(5), 307-317. doi:10.1016/j.recot.2015.02.001 PMID:25835142

Dasgupta, A., \& Chandra, B. (2016). Evolving motives for fair trade consumption: A qualitative study on handicraft consumers of India. Anthropologist, 23(3), 414-422. doi:10.1080/09720073.2014.11891962

Dash, M. (2010). Buyers' Preferences for Purchase of Selected Handicrafts With Special Reference to Orissa. The IUP Journal of Management Research, IX(6), 38.

Deale, C. S., \& Lee, S. H. (2021). An Exploratory Study of Hospitality and Tourism Stakeholders' Perceptions of Professional Etiquette. Journal of Hospitality \& Tourism Education, 33(1), 43-56. doi:10.1080/10963758. 2019.1654891

Fadda, N. (2020). Entrepreneurial behaviours and managerial approach of lifestyle entrepreneurs in surf tourism: An exploratory study. Journal of Sport \& Tourism, 24(1), 53-77. doi:10.1080/14775085.2020.1726801

Ferreira, J., Sousa, B. M., \& Gonçalves, F. (2019). Encouraging the subsistence artisan entrepreneurship in handicraft and creative contexts. Journal of Enterprising Communities, 13(1-2), 64-83. doi:10.1108/JEC-092018-0068

Ghouse, S. (2012). Indian handicraft industry: Problems and strategies. International Journal of Management Reviews, 2(7), 1183-1199.

Hinkin, T. R. (1995). A Review of Scale Development Practices in the Study of Organizations. Journal of Management, 21(5), 967-988. doi:10.1177/014920639502100509

Hogan, T. P., \& Murphy, G. (2007). Recommendations for preparing and scoring constructed-response items: What the experts say. In Applied Measurement in Education (Vol. 20, Issue 4, pp. 427-441). Taylor \& Francis Group. doi:10.1080/08957340701580736

HPSH\&HCL. (2010). Himachal Pradesh State Handicrafts \& Handloom Corporation Limited. Government of Himachal Pradesh.

IBEF. (2020). About Himachal Pradesh: Information On Tourism, Industries, Geography. https://www.ibef. org/states/himachal-pradesh.aspx 
Ibrahim, Y. A. R. A. R. (2010). Homestay Program and Rural Community Development in Malaysia. Journal of Ritsumeikan Social Sciences. https://d1wqtxts1xzle7.cloudfront.net/33995338/vol02_03. pdf? $1403251178=\&$ response-content-disposition=inline $\% 3 B+$ filename\%3DTourism_industry_is_the_ second_largest_c.pdf\&Expires $=1613638982 \&$ Signature $=\mathrm{G} \sim \mathrm{i} 80$ ONmoNU7G2AMrd19jxMoknJ8aPJOz6GRQkevzINS0rkfZU15ZsX6kV

IMARC. (2020). Handicrafts Market: Global Industry Trends, Share, Size, Growth, Opportunity and Forecast 2021-2026. https://www.imarcgroup.com/handicrafts-market

Jaeschke, R., Singer, J., \& Guyatt, G. H. (1990). A comparison of seven-point and visual analogue scales. Controlled Clinical Trials, 11(1), 43-51. https://doi.org/10.1016/0197-2456(90)90031-V

Joshi, G., \& Dhar, R. L. (2020). Green training in enhancing green creativity via green dynamic capabilities in the Indian handicraft sector: The moderating effect of resource commitment. Journal of Cleaner Production, 267, 121948. https://doi.org/10.1016/j.jclepro.2020.121948

Kaplanidou, K., \& Vogt, C. (2007). The Interrelationship between Sport Event and Destination Image and Sport Tourists' Behaviours. Journal of Sport \& Tourism, 12(3-4), 183-206. https://doi.org/10.1080/14775080701736932

Keskitalo, E. C. H., Schilar, H., Heldt Cassel, S., \& Pashkevich, A. (2021). Deconstructing the indigenous in tourism. The production of indigeneity in tourism-oriented labelling and handicraft/souvenir development in Northern Europe. Current Issues in Tourism, 24(1), 16-32. https://doi.org/10.1080/13683500.2019.1696285

Kim, H. B., Choi, S., Kim, B., \& Pop-Eleches, C. (2018). The role of education interventions in improving economic rationality. Science, 362(6410), 83-86. https://doi.org/10.1126/science.aar6987

Koenig Kellas, J., \& Trees, A. R. (2006). Finding Meaning in Difficult Family Experiences: Sense-Making and Interaction Processes During Joint Family Storytelling. Journal of Family Communication, 6(1), 49-76. https:// doi.org/10.1207/s15327698jfc0601_4

Kotler, P., \& Hall, G. A. (2004). Principles of marketing. 14th. In Pearson Prentice Hall (14th ed.). Pearson Prentice Hall. http://cdn3.j2ski.com/kch2/16-maximus-mertz-jr/IpolcDbYFHI-principles-of-marketing-11th.pdf

Kozak, M. (2002). Comparative analysis of tourist motivations by nationality and destinations. Tourism Management, 23(3), 221-232. https://doi.org/10.1016/S0261-5177(01)00090-5

Kuo, H. I., Chen, C. C., Tseng, W. C., Ju, L. F., \& Huang, B. W. (2008). Assessing impacts of SARS and Avian Flu on international tourism demand to Asia. Tourism Management, 29(5), 917-928. https://doi.org/10.1016/j. tourman.2007.10.006

Littrell, M. A., Anderson, L. F., \& Brown, P. J. (1993). What makes a craft souvenir authentic? Annals of Tourism Research, 20(1), 197-215. https://doi.org/10.1016/0160-7383(93)90118-M

Mbaiwa, J. E. (2004). Prospects of basket production in promoting sustainable rural livelihoods in the Okavango Delta, Botswana. International Journal of Tourism Research, 6(4), 221-235. https://doi.org/10.1002/jtr.477

Militz, T. A., Kershler, D., \& Southgate, P. C. (2021). Informing Artisanal Pearl and Pearl-Shell Handicraft Production for the Cruise Tourism Market Through Analysis of Intended Purchase Behavior. Tourism in Marine Environments, 16(1), 45-58. https://doi.org/10.3727/154427320X15958571868603

Mustafa, M. (2011). Potential of sustaining handicrafts as a tourism product in Jordan. International Journal of Business and Social Science, 2(2), 145-152.

Naidu, S., Chand, A., \& Southgate, P. (2016). People and places in the global economy Article information. Journal of Enterprising Communities, 10(4), 29.

Nair, B. B., \& Dileep, M. (2020). Responsible Tourism: Integrating Social Sustainability through Women Empowerment. Ereview of Tourism Research, 18(3), 424-450.

Nair Balakrishnan, B., \& Sinha, S. (2020). COVID-19 and future travel perspectives: An empirical study on travel history and travel decision choices. Enlightening Tourism. A Pathmaking Journal, 10(2), 306-322. 10.33776/ et.v10i2.4919 
Nayak, J. K., \& Bhalla, N. (2016). Factors motivating visitors for attending handicraft exhibitions: Special reference to Uttarakhand, India. Tourism Management Perspectives, 20, 238-245. https://doi.org/10.1016/j. tmp.2016.10.001

NCAER. (2020). Regional Tourism Satellite Account Himachal Pradesh, 2019-20. Author.

Ormshaw, M. J., Kokko, S. P., Villberg, J., \& Kannas, L. (2016). The desired learning outcomes of school-based nutrition/physical activity health education: A health literacy constructed Delphi survey of Finnish experts. Health Education, 116(4), 372-394. https://doi.org/10.1108/HE-12-2014-0097

Oyekunle, A. O., \& Si, M. S. (2018). The role of design in sustainable development of handicraft industries. African Journal of Science, Technology, Innovation and Development, 10(4), 381-388. https://doi.org/https:// doi.org/10.1080/20421338.2018.1461968

Purnomo, A. (2021). Identification of Potency for Developing Business Value of Negeri Katon Tourism Village, District of Pesawaran, Lampung Province. Turkish Journal of Computer and Mathematics Education, 12(3), 2510-2516. https://doi.org/10.17762/turcomat.v12i3.1243

Setiyati, E. A., \& Indrayanto, A. (2011). Outsourced Souvenirs: An Investigation towards Authenticity Anxiety and Tourist"s Purchase Behaviour. International Conference on Social Science, Economics and Art 2011, 196-201.

Sinha, S., \& Nair, B. B. (2020). Impact of COVID-19 on destination choice: an empirical study on sociodemographic determinants of future travel behaviour. Anatolia, 32(1), 128-131. 10.1080/13032917.2020.1839523

Teo, P.-C., Geat, J. L. K., Ho, T. C. F., Jang, Y.-T. J., \& Li, A. L. C. (2020). Analysis on Competitiveness of the Handicrafts Industry: A Case of Sri Lanka. International Journal of Academic Research in Business and Social Sciences, 10(6). https://doi.org/10.6007/IJARBSS/v10-i6/7275

Toops, S. (1993). Xinjiang's handicraft industry. Annals of Tourism Research, 20, 88-106.

Satyajit Sinha is a Research Associate. He received his PGDM in International Business from Indian Institute of Tourism and Travel Management, Gwalior, India in 2014 and PhD from Central University of Himachal Pradesh, India in 2021. He received Junior Research Fellowship in 2014. His main areas of interest are crisis management, over-tourism, and pro-poor tourism. 